\title{
Beware the White Rabbit: Tim Burton's Alice in Wonderland and A. G. Howard's Splintered as Gothic Cautionary Tales for Young Girls
}

\section{Abstract:}

The aim of this article is to speculate on the meaning that Lewis Carroll's (1865, 1871) Alice's journey through dark Wonderland has acquired in two examples of contemporary YA fiction, Tim Burton's 2010 film adaptation and A. G. Howard's 2013 Splintered novel, both depicting Wonderlands that are more dangerous and threatening than what Carroll himself envisioned in his novels. The study shows how Alice's gender and the fact that she is now portrayed as an adolescent affect her narrative. Among other reasons, the author of the paper argues that the fact that Carroll's books feature a girl protagonist who wanders alone in a strange land, together with a long-standing tradition of warning girls against doing precisely this, has resulted in the proliferation of YA narratives that turn Carroll's 'golden afternoon' into a Gothic nightmare.

\section{Key words:}

adaptation, A. G. Howard, Alice's Adventures in Wonderland, Alice in Wonderland, children's and young adult literature, fantasy, Gothic, Lewis Carroll, rewriting, sequel, Splintered, Tim Burton, Through the Looking-Glass, and What Alice Found There

\section{Uwaga na Białego Królika. Alicja w Krainie Czarów}

Tima Burtona oraz Alyssa i czary A. G. Howard jako gotyckie opowieści ku przestrodze dla dziewcząt

\section{Abstrakt:}

Celem artykułu jest refleksja nad znaczeniem, jakie podróży Alicji wykreowanej przez Lewisa Carrolla $(1865,1871)$ przez mroczną Krainę Czarów nadają dwa młodzieżowe teksty kultury: filmowa adaptacja powieści w reżyserii Tima Burtona

* Auba Llompart Pons - PhD, works at the Department of Translation, Interpreting and Applied Languages of the Faculty of Education, Translation and Humanities at the University of Vic - Central University of Catalonia (Spain). Her research interests include children's and young adult literature, fairy tales, Gothic studies, and gender studies. Contact: auba.Ilompart@uvic.cat. 
z 2010 roku i powieść Alyssa i czary A. G. Howard (2013). Oba przedstawiają Krainę Czarów jako miejsce groźniejsze i bardziej niebezpieczne niż to z oryginału Carrolla. Artykuł ukazuje wpływ, jaki na narrację mają płeć i nastoletni wiek Alicji. Autorka tekstu udowadnia, że jednym z powodów, dla których tak wiele tekstów młodzieżowych przekształca Carrollowskie „złote popołudnie” w gotycki koszmar, jest fakt, że główna bohaterka oryginalnej powieści to dziewczynka, która samotnie podróżuje po dziwnej krainie, podczas gdy właśnie przed tym przestrzega się dziewczynki od bardzo dawna.

\section{Słowa kluczowe:}

adaptacja, A. G. Howard, Przygody Alicji w Krainie Czarów, Alicja w Krainie Czarów, literatura dziecięca i młodzieżowa, fantastyka, gotyk, Lewis Carroll, rewriting, sequel, Alyssa i czary, Tim Burton, O tym, co Alicja odkryła po drugiej stronie Lustra

\section{Alice in Young Adult Fiction}

S ince their publication, Alice's Adventures in Wonderland and Through the $\checkmark$ Looking-Glass, and What Alice Found There by Lewis Carroll (1865/1998a, 1871/1998b) have inspired countless rewritings, sequels, adaptations, and imitations (Sigler, 1997). Alice ${ }^{1}$ has also transgressed the confines of literature and film to become a transmedia phenomenon (Kérchy, 2016), inspiring video games, TV series, theatre plays, art exhibitions, graphic novels, and fan fiction, among other cultural productions. Young adult (YA) fiction has been no exception when it comes to appropriating Alice and reimagining it for its own purposes. In the last couple of decades, Alice has been adapted again for the big screen in Disney's Alice in Wonderland (Zanuck, Roth, Todd, Todd, \& Burton, 2010) and its sequel (Roth, Todd, Todd, Burton, \& Bobin, 2016), with screenplays by Linda Woolverton, and YA authors have also incorporated Wonderland in their novels. In fact, many of these books explicitly advertise themselves as Alice-inspired stories, as is the case with the Splintered trilogy by A. G. Howard (2013-2015), The White Rabbit Chronicles by Gena Showalter (2012-2017), The Looking Glass Wars by Frank Beddor (2004-2009), Insanity by Cameron Jace (2013) and the rest of the eponymic series, the short story collection Beware the Little White Rabbit, edited by Shannon Delaney and Judith Graves (2015), or Alice in Deadland by Mainak Dhar (2011) and its sequels, to name a few.

1 In this article, 'Alice' will be used to refer to the two novels by Lewis Carroll, Alice's Adventures in Wonderland and Through the Looking-Glass, and What Alice Found There (1865/1998a, 1871/1998b). 
Apart from their narrative structure, source of inspiration, and target audience, what many of these YA Alice stories have in common is that they are Gothic in form and content, and they turn Wonderland into a dark and menacing place, following a trend that started in the 1930s, according to Will Brooker $(2004$, p. xv). In these works, Alice is no longer a seven-and-a-halfyear-old little girl as in Carroll's books. She has grown into an adolescent who has to fight monsters, villains, zombies, and, ultimately, herself, her fears, and her own disturbed psyche. What is more, waking up is not enough to make her dark Wonderland - to use Brooker's expression (p. 229) - disappear. As Catherine Siemann (2012) puts it, this "Victorian children's adventure has become unsuitable for children" (p. 175), and it has crossed over into YA fiction.

Previous scholarship has proposed many reasons that may account for Alice's appeal, "[y]et the key to the enduring power of these two Victorian children's fantasy novels and their pinafored young heroine has both eluded and absorbed critics ever since the books' publications," as stated by Carolyn Sigler (1997, p. xiii). She, however, suggests that their success may lie precisely in the fact that, "like dreams, [the Alice books] can mean whatever readers need [emphases in original] them to mean" (p. xiv). Thus, the main question that I seek to explore here is what Alice's journey through the dark Wonderland means in two selected examples of contemporary YA Gothic inspired by Carroll's novels: Tim Burton's 2010 sequel/adaptation ${ }^{2}$ and A. G. Howard's Splintered series, ${ }^{3}$ with special emphasis on the first book. Burton's film will be treated as YA fiction here insomuch as it was rated PG in the United States, which suggests that some content might be unsuitable for children, and that young adults and adults are its target audience. As for Howard's novel, it is clearly aimed at a teenage readership.

Both narratives rework Carroll's Alice in a Gothic light, 'Gothic' being understood here as a non-realistic representational mode centrally concerned with depictions of fear and transgression. In these narratives, dark Wonderlands mirror the female protagonists' fears and their disturbed psyches, also fitting into Dani Cavallaro's (2002) definition of the Gothic as "a cultural discourse that utilizes images of disorder, obsession, psychological disarray and physical

2 Although the film was conceived as a sequel to, rather than an adaptation of, Carroll's novels, I adhere to Kamila Elliott's (2010) reading of the film as an adaptation because: "It adapts many scenes and most characters from the Alice books; it quotes many of its lines verbatim" (p. 194).

3 Splintered (Howard, 2013) is the first novel in the eponymous series. It was followed by Unhinged (Howard, 2014), Ensnared (Howard, 2015a) and Untamed (Howard, 2015b), a collection of stories that expands on some characters from the trilogy. 
distortion for the purposes of both entertainment and ideological speculation" (p. vii). What I contend here is that, in a cultural context that constantly worries about young women's safety, Burton and Howard have turned Alice into Gothic cautionary tales that warn against the dangers that young women are exposed to and try to propose ways in which they can become empowered. As we will see, their Alice-type protagonists travel to Wonderlands that are more hostile and dangerous than what Carroll himself originally envisioned, only to escape from realities that might be even worse.

\section{Carroll's Alice and the Gothic}

As the term 'Gothic' has been applied to such a wide range of texts and cultural productions, it has become increasingly elusive. According to David Punter (1996a), studying the Gothic nowadays implies that "almost nothing can be assumed, not even the limits of the field" (p. 18). Punter adds that, in contemporary usage, the term 'Gothic' means much more than just "a particular set of characteristics that we relate to eighteenth- and nineteenth-century Gothic fiction"; in the present day, "it has acquired a number of other usages, some of them apparently only tangentially related to the 'original Gothic" (pp. 1-2). Thus, in an attempt to find a definition that applies to all the different cultural manifestations that we instinctively identify as Gothic, Punter (1996b) concludes that the Gothic is "a mode - perhaps the mode - of unofficial history [emphasis in original]" (p. 187); the mode that tells us that "realism' is not the whole story" (p. 186). Interestingly, this is precisely what the narratives discussed here seem to be telling us through their Gothicized renditions of Wonderland: that the Alice books are not the whole story and there is actually more darkness in the original "golden afternoon" (Carroll, 1865/1998a, p. 5) than meets the eye.

Although the idea that Carroll's novels are Gothic texts has been refuted by several scholars, in this article, I propose a Gothic reading of Alice to highlight the Gothic potential that the novels have and which contemporary creators of YA fiction - like Burton and Howard - seek to exploit. In The Gothic in Children's Literature: Haunting the Borders, Anna Jackson, Karen Coats, and Roderick McGillis (2008) affirm that, despite the tendency to read Alice's journey as a frightening experience, "Alice in Wonderland is not a Gothic text" (p. 3); they go on to argue that:

[...] the logic that is so displaced in this world [Wonderland], the morals and manners that are overturned, belong to the didactic texts that had been designed 
to take the Gothic story's place. When the genre of didactic narrative is turned back on itself, and indeed turned upside down and inside out, the result is not a return to the Gothic stories children used to read before children's literature was invented, but the beginning of a new children's literature tradition, the tradition to which all subsequent children's literature belongs (p. 3).

Along the same lines, Frankie Morris (2005) affirms that "Carroll had no intention of giving his young readers nightmares" (p. 183). Yet, it could very well be that Carroll unknowingly and unintentionally produced a narrative that is disturbing to the child reader, who might perceive something that looks harmless and ludicrous to an adult as scary and threatening. As C. S. Lewis (1963/2006) once stated: "We do not know what will or will not frighten a child" (p. 23). In fact, Brooker (2004) explains how one of his correspondents admitted to have met people who "disliked the [Alice] books and found them threatening when they were read to as children" (p. 300). Similarly, Morris (2005) alludes to journalist and Punch editor Malcolm Muggeridge's declaration that "[f]rom a child's point of view the story is full of an indefinable and incomprehensible horror. [...] Alice is a very sick book indeed" (p. 183). We could argue that characters like the Queen of Hearts are grotesque figures rather than Gothic villains, and that they are not intended to produce fear, but a comic effect. Yet the deep connection between the comic and the Gothic should not be overlooked. As Jackson, Coats, and McGillis (2008) themselves argue, "the exaggerated grotesqueries of the villains" and "the subtle play of parody" have "been at the heart of Gothic since its inception" (p. 4).

Other reasons that scholars attribute to our perception of Alice as dark and disturbing have less to do with the texts themselves, and more to do with extratextual elements, such as Carroll's biography and the novels' illustrations, for example, the first professional ones by John Tenniel. Regarding the former, there are two dominant ways of seeing Carroll and Alice, as Brooker (2004) asserts:

[...] one that evolved during Carroll's lifetime, and the other with its origins in the 1930s. [...] In the first discourse, Carroll is a sainted innocent, his books are joyous nonsense and Alice is his muse. In the other, Carroll is a paedophile, his books are dark allegories, and Alice is his obsession (p. xv).

The latter discourse would continue throughout the $20^{\text {th }}$ century with psychoanalytical readings of Carroll's novels (pp. xvi-xvii). Despite their previous affirmation that Alice is not a Gothic text, Jackson, Coats, and McGillis (2008) also admit that "Alice disappears down a hole into a world which seems to invite exactly the same kind of psychoanalytic reading that the Gothic genre as a whole insistently calls for" (p. 3). 
Other factors that connect Alice with the Gothic tradition are the dark feel and grotesquerie of the illustrations that have accompanied Carroll's texts through their many editions (Brooker, 2004, pp. 107-111; Morris, 2005, p. 184), ${ }^{4}$ the "blurry line between nonsense and terror" (Lerer, 2008, p. 191), and a commercial need to please contemporary audiences. Sonya Sawyer Fritz (2011) proposes that, by turning Alice's journey "into a rite of passage in which she must overcome her fears and prove herself in order to return home and be accepted into the adult company" (p. 115), filmmakers - and she refers to Harry Harris, in particular - "infuse Wonderland with a purpose where there was none before" (p. 115-116). This is supposed to give the story a coherent narrative arc, more engaging for the contemporary public than the "disconnected dream sequences" (p. 116) of Carroll's original. Thus, Alice's journey "from frightened to confident is meant to be both fulfilling and familiar to the children who watch it" (p. 117), a pattern that, as we will see, can be found in the Gothic narratives by Burton and Howard discussed here. This connects with Sigler's previously quoted statement that, precisely because of its lack of a predetermined meaning, Alice can be made to mean whatever readers want it to mean. Curiously, though, by giving a specific significance to Alice's journey, these narratives might actually be losing the nonsensical quality that made us perceive Carroll's novels as disturbing in the first place. As Kamila Elliott (2010) puts it (referring specifically to Tim Burton's film):

[...] the film makes the narrative structure of Carroll's Jabberwocky poem the narrative structure of the whole film [...] to produce a familiar and decisive ending to the film, in which Alice herself slays the Jabberwocky. Killing the Jabberwocky is a structuring principle not only for the film's plot but also for its destruction of Carroll's nonsensical aesthetic. The poem is the epitome of nonsense; to kill the Jabberwocky is to kill nonsense (p. 194).

Apart from all these connections between Alice and the Gothic, I propose another reason that may account for this trend to build upon the 'dark Wonderland' tradition in Alice-inspired YA fiction, which has to do with the protagonist's gender: the fact that it is an adventure story about a girl who wanders alone in a strange land. As American children's author Daniel Handler

4 Brooker (2004) mentions not only John Tenniel's first edition drawings, but also Arthur Rackham's 1907 Wonderland with its “somber atmosphere” (p. 107), Mervyn Peake's macabre images, and Peter Blake's 1970s watercolours that the scholar describes as "uncanny snapshots from a world of grotesques" (p. 111). 
(2015), best-known as Lemony Snicket, stated in his article The Righteous Anger of Girls:

I agree, and don't we all? The world is pretty hard on girls [emphasis in original]. It's one reason I put so many of them in books. The narrative is more interesting if there are more obstacles. A man walking alone down a road at night may or may not be a good story; turn him into a 12-year-old girl, and it's already gripping. The vulnerability and the danger - the wrongness of a young girl wandering about - are a shortcut to creating a good read.

"A young girl wandering about" is precisely what Carroll's Alice novels revolve around, and Handler describes this as an image of "vulnerability", "danger," and "wrongness," in other words, an image of transgression. This suggests the idea that Carroll's Alice might appeal to us nowadays, among other reasons, because of its potential to produce empowering narratives for young women, at the same time that it reveals the disquieting idea that, to become empowered, young girls need to transgress those boundaries that we have set for their safety; they need to visit a dark Wonderland.

Whereas male protagonists in children's and YA fiction have often been allowed to enjoy adventures in fantasylands, girls have usually been confined to the realm of the domestic and pressured to grow up. As Amy Billone (2004) affirms, "until very recently childhood has been an unsettling masculine space" (p. 179). Billone exemplifies this by comparing Alice to J. M. Barrie's (e.g. 1911) Peter Pan, whose "gender allows him to remain in Neverland (to control it, in fact) while Alice's gender causes her fantasy universe to distort into a nightmarish mirror reflection" (p. 179). Furthermore, in fantasy literature for young readers, there also seems to be more pressure on girls to be 'grown-up' than on boys. Billone mentions the example of Wendy, who assumes a motherly role in Neverland, while her brothers go on exciting adventures with Peter and the Lost Boys. The author also refers to Hermione in the Harry Potter series (Rowling, 1997-2007), who often acts like a mother or elder sister towards Harry and Ron. This suggests that, even when girls are allowed to travel to fantasylands, their experiences tend not to be as adventurous as the ones of their male companions, and they are less likely to be freed from the roles that they are expected to fulfil in their real worlds. A similar pattern can be found in the fairy-tale tradition, which all these works of fiction draw from: girls are often locked in for protection or warned against the dire consequences of wandering alone in the woods. According to Seth Lerer (2008), "[f]airy-tale girls are often in the forest, and they differ from the boys. Boys are explorers, woodcutters, path-makers, or controllers. 
Girls remain lost or threatened" (p. 231). ${ }^{5}$ Of course, there are exceptions to this but, in the main, domesticity has been a predominant feature in girls' fiction and, as we will see, in female Gothic as well.

Unlike other fictional girls, Carroll's Alice visits and discovers a fantasyland on her own, with no male protectors or helpers, thus breaking away from this domestic tendency of girls' fiction. As Anna Kérchy (2016) observes, Alice has been seen as the embodiment of many different qualities, depending on the eyes of the beholder, and what feminists see in her is "an empowering alternative for the claustrophobic, domestic narratives of feminine helplessness" (p. 6). Her journey, however, is by no means free of anxiety. Comparing Alice to the $\mathrm{O} z$ books by L. Frank Baum (e.g. 1900, 1904), ${ }^{6}$ Alison Lurie (2003) remarks that:

Unlike Dorothy and Ozma, who collect loving friends and companions on their journeys, Alice travels alone, and the strange creatures she meets are usually indifferent, self-absorbed, hostile, or hectoring. Rather than helping her, as Dorothy's companions do, they make unreasonable demands: she is told to hold a screaming baby, do impossible math problems, and act as a ladies' maid (p. 43).

Thus, far from enjoying carefree childish fun in this alternative world outside the home, Alice's adventures in Wonderland and through the Looking-Glass often verge on the disturbing. Yet, what is striking about the original Alice is that, despite the unsettling nature of her adventures, she feels anxious and confused but never afraid. On the contrary, when the Queen of Hearts threatens to behead her at the end of the first book, Alice fearlessly exclaims: "You're nothing but a pack of cards!" (Carroll, 1865/1998a, p. 108), which causes Wonderland to disappear and Alice to wake up from her dream.

However, even if her journey triggers an identity crisis, Alice's story is not a cautionary tale of the "Little Red Riding Hood" sort, which punished young women for their innocence and curiosity. As Perry Nodelman (2008) puts it, Alice is allowed to experience "the wonderfully frightening and frighteningly wonderful state of being in flux, uncertain, not finished yet" (p. 40). Along the same lines, Alex Brink (2014) observes that "Carroll never punishes his female

5 With the exception of Gretel, "who masterminds her and her brother's salvation" (Lerer, 2008, p. 231).

6 Interestingly, The Wonderful Wizard of $\mathrm{Oz}$ by Baum (1900) has also been reworked from a Gothic perspective in narratives like Dorothy Must Die by Danielle Paige (2013- ), and other volumes in the series of the same name, or the TV show Emerald City (Arnold, Friedman, 2016-2017). 
protagonist for indulging her curiosity" (p. 4). In other words, venturing outside the home threatens Alice's sense of a stable identity, but at the same time, there seems to be an implicit acknowledgment that this is necessary for one's maturation and self-discovery; that everyone should have the right to leave their ivory tower and visit Wonderland. What is more, Carroll's use of the dream as a narrative device implies that his heroine is never in real danger. For all these reasons, I believe that Alice can be read as a feminist icon, in line with what Roberta Seelinger Trites (1997) defines as the feminist children's novel: “[...] a novel in which the main character is empowered regardless of gender. [...] in a feminist children's novel, the child's sex does not provide a permanent obstacle to her development" (p. 4).

The two YA Alice stories that will be examined in the next section attempt to build upon this interpretation of Alice as a feminist heroine that emerges triumphant from her Gothic experience. However, giving a specific meaning to Alice's journey and emphasizing the Gothic potential of both Wonderland and the real world, Burton and Howard have put obstacles in Alice's way that were not originally there, and these obstacles are directly related to the protagonist's gender. They have encased their Alices inside a narrative that might turn out to be more oppressive and conservative than its Victorian precedent, to the extent that the original Alice might have actually enjoyed more liberation than her $21^{\text {st }}$-century descendants.

\section{Burton's Alice and Howard's Alyssa}

In Burton's film and Howard's series, Wonderland is not a dream. Alice and Alyssa are in real danger, which may partly account for the fact that, in both narratives, the target audience has aged, and so has Alice, who is nineteen in Burton's film and sixteen at the beginning of Howard's trilogy. Alice has become a teenager, and what was initially conceived as a children's story has now evolved into YA fiction. This means that these two heroines will inevitably be faced with preoccupations that the original Alice did not have. Whereas Carroll's little girl followed the White Rabbit because she was "tired of sitting by her sister on the bank, and of having nothing to do" (Carroll, 1865/1998a, p. 9), the heroines at stake here have other motivations to run away from their realities: Alice Kingsleigh (Mia Wasikowska) seeks to avoid a loveless marriage, and Alyssa Gardner has to save herself from being sent to a mental institution. As Siemann (2012) states, "in the first decade of the twenty-first century, the controlled menace of the original is transformed into outright violence, insanity, 
and sexual threat. In order to negotiate this darkening terrain, Alice is portrayed as a young woman in her teens or early twenties" (p. 175). The fact that Burton's Alice and Howard's Alyssa are teenage girls therefore allows their creators to explore the dangers that young women face. Wonderland has become darker because Alice has become older in a world that victimises and sexualises young women. Yet the opposite might also be true: authors and filmmakers have made Alice age to be able to further explore the endless possibilities and meanings of the dark Wonderland.

Set in the Victorian era, Tim Burton's film takes place years after the events narrated in Through the Looking-Glass. Alice Kingsleigh, who has just lost her father and suffers from recurring nightmares, receives a marriage proposal from Hamish (Leo Bill), an aristocratic man that she does not love. Feeling pressured by her society's expectations to accept him, Alice escapes and soon finds herself following a White Rabbit (Michael Sheen) and falling down the rabbit hole. This takes her to Underland, a devastated version of both Wonderland and the Looking-Glass world under the tyranny of the Red Queen (Helena Bonham Carter) - a merging of the Queen of Hearts and the Red Queen from Carroll's books. Like her Carrollian counterpart, Burton's Alice also goes through an identity crisis, as the Underland inhabitants wonder whether she is the real Alice or not, the Alice that - according to the Oraculum owned by the Caterpillar (Alan Rickman) - will slay the Jabberwocky (Christopher Lee) and put an end to the Red Queen's reign of terror. Alice will finally learn that she has been there before, and that what she thought were recurring nightmares were actually childhood memories of her previous visits to Underland, which correspond to the events described in Carroll's novels. When Alice finally accepts her role and saves Underland, she returns to the real world empowered enough to reject Hamish's proposal and do what she wants to do: set off to China on a trading ship. As Alice finally proclaims: "This is my life. I decide what to do with it" (Zanuck, Roth, Todd, Todd, \& Burton, 2010).

In Burton's Alice, there is a sense that the decadence of Underland reflects how Alice herself feels in her real world: constricted by the tyranny of Victorian ideals and in need of liberation. It is the White Queen (Anne Hathaway) who teaches her the valuable lesson that Alice will have to apply in both worlds: "You cannot live your life to please others. The choice must be yours. Because when you step out to face that creature [the Jabberwocky], you will step out alone" (Zanuck, Roth, Todd, Todd, \& Burton, 2010). These words imply that there is a strong connection between Underland and Alice's everyday reality, and that killing the Jabberwocky is in fact metaphorically killing her fears of challenging her society's expectations. Burton's heroine has run away to a fantasy land 
that is full of perils to escape something that is even more frightening: being locked inside the home with a patriarchal figure, which is, incidentally, the fate of many victims/heroines of female Gothic. In fact, as Alice is played by actress Mia Wasikowska, who would later play Jane Eyre in Alison Owen, Paul Trijbits, and Cary Fukunaga's (2011) adaptation of Charlotte Brontë's (1847) novel, it is inevitable to relate Burton's Alice to this other Victorian heroine, confined in Mr. Rochester's Thornfield Hall. Burton's Alice, however, actually occupies a position in her narrative that corresponds to both male and female Gothics. Like the female Gothic, the film warns against the dangers of marriage and patriarchy, but the alternative to this is the masculine world of adventure, war, and entrepreneurship. As Kate Ferguson Ellis (1989) states, the home in the Gothic tradition is "the place from which some (usually 'fallen' men) are locked out, and others (usually 'innocent' women) are locked in" (p. ix). Alice rejects the home and escapes a potential female Gothic experience by becoming masculinised in the world outside. As Brink (2014) argues:

Burton's modern adaptation pushes Alice into traditional male roles, such as becoming a knight in shining armor and embarking on a career in the capitalist trade industry, to prove her worth. Burton's attempt to shatter the mold of past female Disney characters ultimately suggests that female characters can only gain equality and power by shirking femininity and instead embodying masculine qualities (p. 3).

In her journey through Underland, Alice becomes a warrior that actively fights and slays the Jabberwocky, and she adopts a traditional male role upon returning to her real world by entering the trading business.

As in the previously discussed feminist interpretation of Carroll's novels, the journey through the dark Wonderland is presented as anxiety-inducing, but necessary for the young woman's maturation and empowerment. As Siemann (2012) affirms, Burton's Alice "is, or wants to be, a female empowerment fantasy" (p. 183). Despite being set in the Victorian era, Siemann argues, "what Alice faces in this imagined Victorian setting are the concerns of a twenty-first-century young woman coming into her own, seeking autonomy through professional achievement" (p. 186). Traditional femininity and marriage are represented as oppressive and undesirable in the film. Like Carroll, Burton breaks away from the domesticity that characterises girls' fiction and the female Gothic, the repeated idea "throughout most male literature, [that] a sweet heroine inside the house [...] is opposed to a vicious bitch outside" (Gilbert \& Gubar, 1979/2000, p. 29). Yet, what problematizes the reading of Burton's film as a feminist narrative is the fact that the alternative that the film offers to traditional femininity is 
traditional masculinity. Burton masculinises not only Alice, but also her journey, as Alice's dialogic, peaceful interactions with the creatures of Wonderland in Carroll's novels have been replaced by action and violence in this adaptation. Burton's Alice can be read as a cautionary tale insomuch as it warns young women against the dangers of traditional femininity like the female Gothic does, and it seems to imply that, for young women, perils are both inside and outside the home: Alice is in danger both in her real world and in Underland, and her chances of survival depend on her willingness and capacity to adopt a more masculine role.

A. G. Howard's Splintered has much in common with Burton's film: it takes place years after the events in Carroll's books, it reimagines Wonderland as a dark place, and its protagonist is a teenage girl, Alyssa Gardner. As The Bulletin of the Center for Children's Books announced, establishing a connection between the two Alice narratives, "[f] ans of dark fantasy, as well as of Carroll's Alice in all her revisionings (especially Tim Burton's), will find a lot to love in this compelling and imaginative novel" (Howard, 2013, back cover). Living in the present day, Alyssa is a descendant of Alice Liddell, and she is developing a strange affliction. Like the other women in her family, she hears whispers and sees what seem to be glimpses of another world, a condition that is strongly reminiscent of schizophrenia and which already got Alyssa's mother sent to a mental institution. Determined to save herself and her mother, Alyssa sets off to prove that she is not mentally ill, and that the world she sees in her hallucinations is actually real. She will soon discover that this world is none other than Wonderland, and that what Carroll described in his novels was actually true: her ancestor Alice Liddell did travel to Wonderland and told Carroll about it when she came back, inspiring him to write his stories. In Howard's reimagining, what Carroll's novels depicted was actually a little girl's innocent vision of a much darker and more sinister place. As Alyssa remarks when she sees what Wonderland is really like, "Alice must've been too young to understand what she saw. Maybe her mind blocked out the darker details" (p. 104). In the end, Alyssa will find out that her ancestor was not Alice Liddell at all, but Queen Red, who returned to the human world and took Alice's place, unleashing a curse on all her female descendants. Throughout her journey, Alyssa will also have to come to terms with her attraction for Jeb, her friend from the human world who accompanies her in her quest, and Morpheus, Howard's version of Carroll's Caterpillar. Whereas Splintered mostly focuses on Alyssa's discovering her true origins, in the subsequent books, Unhinged (Howard, 2014) and Ensnared (Howard, 2015a), Alyssa will return to Wonderland to fight Queen Red and save her two worlds, very much like Burton's Alice liberating Underland from the Red Queen. 
As Siemann (2012) affirms, "[m]any of the adult Alices are victims of other types of threats, including madness and death" (p. 180), and this is certainly the case of Alyssa Gardner. The playful madness of Carroll's Wonderland has acquired connotations of psychological disorder in Howard's re-imagining. If Burton's heroine had to escape the possibility of being locked inside a loveless household, Alyssa is also running away from a potential female Gothic narrative: she will be sent to a mental institution if she fails to prove that she is not ill but cursed. Like Burton's Alice, Alyssa is in danger both in her real world and in her fantasy world, reinforcing the idea that young women are unsafe everywhere. Not even their psyches are safe places. In Burton's and Howard's works, the protagonists' contact with their fantasy worlds endangers them physically and mentally. Ever since she visited Wonderland when she was a little girl, Burton's Alice has been haunted by nightmares. Similarly, the presence of Alyssa's ancestor in Wonderland triggered the curse that has mentally affected the women in her family only the women, a fact that is strongly reminiscent of how, in the past, hysteria was regarded as an exclusively feminine disease. This and the fact that the novels are narrated in the first person by Alyssa, the 'madwoman' herself, suggest that Howard will be challenging patriarchal narratives that have traditionally depicted subversive women as 'freaks' or, in the words of Sandra M. Gilbert and Susan Gubar (1979/2000), as madwomen in the attic. Despite this interesting premise, however, the male characters in the story and the presence of the romantic plot ultimately undermine Alyssa's empowerment and self-discovery.

Both Burton and Howard hint at the dangers that young women have to face for being either too traditional or too subversive. In contrast to Burton, however, Howard's solution to surmount these difficulties and keep young women safe is not to adopt a masculine role, but to choose a suitable male partner to guide you through your journey. If Burton's film warned young girls against the dangers of traditional romance, Howard puts romance right at the center of Splintered, to the extent that the love triangle between Alyssa, Jeb, and Morpheus often eclipses what was supposedly Alyssa's main motivation: saving herself and her mother, and discovering who she really is. Significantly, unlike the original Alice and most Alice-type protagonists, Alyssa does not travel to Wonderland alone. She is accompanied by her crush, Jeb, who is described by Alyssa as often being "in surrogate-big-brother mode" (Howard, 2013, p. 13), a patronising attitude that Alyssa finds profoundly attractive: "My entire body goes soft and warm at the gruff possessiveness in his voice" (p. 190). The other male character that guides Alyssa through Wonderland is the dark and seductive Morpheus, who Alyssa describes as "[m]ysterious. Rebellious. Troubled. All those qualities women find irresistible” (p. 360). The love triangle thus takes 
center stage, and the question "Who am I?," so central to the original Alice's journey, is relegated to secondary importance. For most of the novel, Alyssa's judgement is clouded by "those biceps" (p. 114) and "how good his muscles feel" (p. 233), and deciding whether she can trust Morpheus or not and which of the two men would make a more suitable lover seem to become her main preoccupations. Alyssa is torn between the familiar and reliable Jeb from the human world, and the dark and mysterious Morpheus from Wonderland. Even when she is threatened by insanity and death, all that Alyssa can wonder about is: "What's wrong with me? Why should I care about Morpheus's love life, when I've finally kissed Jeb after all these years?" (p. 200). As these passages show, Alyssa is not masculinised like Burton's Alice, but keeping her femininity means that her need for a male helper is emphasised and her agency undermined.

\section{Concluding Remarks}

Burton and Howard are two examples of how present-day YA fiction is exploiting the Gothic and feminist potential already present in Carroll's works to produce empowering narratives about young women who, like Alice, escape the confines of their reality to wander bravely in dark lands, full of peril and adventure. Despite this potential, Alice Kingsleigh and Alyssa Gardner are oppressed female characters, thwarted and conditioned by their gender and their age, and they are eventually enshrined in patriarchal Gothic narratives. They live in worlds that oppress them, only to escape to fantasylands that are liberating and threatening at the same time. Burton's and Howard's dark Wonderlands are as contradictory as the texts themselves: on the one hand, both narratives acknowledge that their heroines need to visit the dark Wonderland to exorcise their fears, acquire self-knowledge, and become empowered. Yet, in both cases, the dark Wonderland is also associated with danger and psychological disorder, almost as if Burton and Howard could not really decide whether journeying through it is a positive or a negative experience for their young female characters. Burton and Howard seem to respect their heroines' thirst for knowledge and exploration, like Carroll did, but both narratives find ways of blaming femininity for the problems that young women face. Thus, the solutions that they propose are to either discard it (like Burton's Alice) or accept their dependence on the protection of a male companion (like Alyssa). In the hands of Burton and Howard, Alice has become a cautionary tale that ultimately represents femininity as an obstacle to one's development and warns against the dangers of being a young woman in a dark world. 


\section{References}

Arnold, M., \& Friedman, J. (Producers). (2016-2017). Emerald City [Television series]. New York, NY: NBC.

Barrie, J. M. (1911). Peter and Wendy. London: Hodder \& Stoughton.

Baum, L. F. (1900). The wonderful Wizard of Oz. Chicago, IL: George M. Hill Company. Baum, L. F. (1904). The marvelous Land of Oz. Chicago, IL: Reilly \& Britton.

Beddor, F. (2004). The Looking Glass wars. London: Egmont.

Beddor, F. (2007). Seeing Redd. London: Egmont.

Beddor, F. (2009). ArchEnemy. London: Egmont.

Billone, A. (2004). The Boy Who Lived: From Carroll's Alice and Barrie's Peter Pan to Rowling's Harry Potter. Children's Literature, 32, 178-202. https://doi.org/10.1353/ chl.2004.0005.

Brink, A. (2014). The masculinization of the female hero in Tim Burton's Alice in Wonderland. Journal of Undergraduate Research and Creative Expression, 1, 1-18.

Brontë, C. (1847). Jane Eyre. London: Smith, Elder \& Co.

Brooker, W. (2004). Alice's adventures: Lewis Carroll in popular culture. London \& New York, NY: Continuum.

Carroll, L. (1998a). Alice's adventures in Wonderland. In Alice's adventures in Wonderland and through the Looking-Glass (H. Haughton, Ed.). London: Penguin. (Original work published 1865).

Carroll, L. (1998b). Through the Looking-Glass, and what Alice found there. In Alice's adventures in Wonderland and through the Looking-Glass (H. Haughton, Ed.). London: Penguin. (Original work published 1871).

Cavallaro, D. (2002). The Gothic vision: Three centuries of horror, terror and fear. London: Continuum.

Delaney, S., \& Graves, J. (Eds.). (2015). Beware the little White Rabbit. Otego, NY: Leap.

Dhar, M. (2011). Alice in Deadland. San Bernardino, CA: CreateSpace.

Elliott, K. (2010). Adaptation as compendium: Tim Burton's Alice in Wonderland. Adaptation, 3(2), 193-201. https://doi.org/10.1093/adaptation/apq009.

Ellis, K. F. (1989). The contested castle: Gothic novels and the subversion of domestic ideology. Chicago, IL: University of Illinois Press.

Fritz, S. S. (2011). Alice still lives here: The implied Victorian reader and film adaptations of Lewis Carroll's Alice books. In L. Weldy (Ed.), Crossing textual boundaries in international children's literature (pp. 109-122). Newcastle upon Tyne: Cambridge Scholars.

Gilbert, S. M., \& Gubar, S. (2000). The madwoman in the attic: The woman writer and the nineteenth-century literary imagination. New Haven, CT: Yale University Press. (Original work published 1979). 
Handler, D. (2015, March 18). The righteous anger of girls. More. Retrieved from https: //thesnicketfile.tumblr.com/post/114174151176/the-righteous-anger-of-girls-bydaniel-handler.

Howard, A. G. (2013). Splintered. New York, NY: Amulet.

Howard, A. G. (2014). Unhinged. New York, NY: Amulet.

Howard, A. G. (2015a). Ensnared. New York, NY: Amulet.

Howard, A. G. (2015b). Untamed. New York, NY: Amulet.

Jace, C. (2013). Insanity. San Bernardino, CA: CreateSpace.

Jackson, J., Coats, K., \& McGillis, R. (Eds.). (2008). The Gothic in children's literature: Haunting the borders. New York, NY \& London: Routledge.

Kérchy, A. (2016). Alice in transmedia Wonderland: Curiouser and curiouser new forms of a children's classic. Jefferson, NC: McFarland.

Lerer, S. (2008). Children's literature: A reader's history, from Aesop to Harry Potter. Chicago, IL: Chicago University Press.

Lewis, C. S. (2006). On three ways of writing for children. In P. Hunt (Ed.), Children's literature: Critical concepts in literary and cultural studies (pp. 17-26). London: Routledge. (Original work published 1963).

Lurie, A. (2003). Boys and girls forever: Children's classics from Cinderella to Harry Potter. New York, NY: Penguin Books.

Morris, F. (2005). Artist of Wonderland: The life, political cartoons, and illustrations of Tenniel. Charlottesville, VA: University of Virginia Press.

Nodelman, P. (2008). The hidden adult: Defining children's literature. Baltimore, MD: John Hopkins University Press.

Owen, A., Trijbits, P. (Producers), Fukunaga, C. J. (Director). (2011). Jane Eyre [Motion picture]. United Kingdom \& United States: Universal Pictures \& Focus Features.

Paige, D. (2014). Dorothy must die. New York, NY: HarperCollins.

Punter, D. (1996a). The literature of terror: A history of Gothic fictions from 1765 to the present day. Volume 1: The Gothic tradition. London \& New York, NY: Routledge.

Punter, D. (1996b). The Literature of Terror: A history of Gothic fictions from 1765 to the present day. Volume 2: The modern Gothic. London \& New York, NY: Routledge.

Roth, J., Todd, S., Todd, J., Burton, T. (Producers), \& Bobin, J. (Director). (2016). Alice through the Looking Glass [Motion picture]. USA: Walt Disney Studios Motion Pictures.

Rowling, J. K. (1997). Harry Potter and the Sorcerer's Stone. London: Bloomsbury.

Rowling, J. K. (1998). Harry Potter and the Chamber of Secrets. London: Bloomsbury.

Rowling, J. K. (1999). Harry Potter and the prisoner of Azkaban. London: Bloomsbury.

Rowling, J. K. (2000). Harry Potter and the Goblet of Fire. London: Bloomsbury.

Rowling, J. K. (2003). Harry Potter and the Order of the Phoenix. London: Bloomsbury.

Rowling, J. K. (2005). Harry Potter and the Half-Blood Prince. London: Bloomsbury. 
Rowling, J. K. (2007). Harry Potter and the Deathly Hallows. London: Bloomsbury.

Showalter, G. (2012). Alice in Zombieland. Toronto: Harlequin.

Showalter, G. (2013). Through the zombie glass. Toronto: Harlequin.

Showalter, G. (2014). The queen of zombie hearts. Toronto: Harlequin.

Showalter, G. (2015). A mad zombie party. Toronto: Harlequin.

Showalter, G. (2017). Kat in Zombieland. Toronto: Harlequin.

Siemann, C. (2012). "But I'm grown up now": Alice in the twenty-first century. NeoVictorian Studies, 5(1), 175-201.

Sigler, C. (Ed.). (1997). Alternative Alices: Visions and revisions of Lewis Carroll's Alice books. Lexington: University Press of Kentucky.

Trites, R. S. (1997). Waking Sleeping Beauty: Feminist voices in children's novels. Iowa City, IA: University of Iowa Press.

Zanuck, R. D., Roth, J., Todd, S., Todd, J., (Producers), \& Burton, T. (Director). (2010). Alice in Wonderland [Motion picture]. USA: Walt Disney Studios Motion Pictures. 